\title{
Inducing Water Productivity from Snow Cover for Sustainable Water Management in Ibrahim River Basin, Lebanon
}

\author{
Talal Darwish $^{1^{*}}$, Amin Shaban ${ }^{1}$, Ivan Portoghese ${ }^{2}$, Michele Vurro ${ }^{2}$, \\ Roula Khadra $^{3}$, Sagedah Saqallah ${ }^{3}$, Laurent Drapeau ${ }^{4}$, Simon Gascoin ${ }^{4}$ \\ and Nabil Amacha ${ }^{5}$ \\ ${ }^{1}$ National Council for Scientific Research, Remote Sensing Center, P.O. Box 11-8281, Beirut, \\ Lebanon. \\ ${ }^{2}$ Consiglio Nazionale delle Ricerche, IRSA - UOS di Bari, viale F. De Blasio 5, 70132 Bari, Italy. \\ ${ }^{3}$ International Centre for Advanced Mediterranean Agronomic Studies, Bari Istituto Agronomico \\ Mediterraneo (CIHEAM, IAM-Bar)i, via Ceglie 9, 70010 Valenzano (BA), Italy. \\ ${ }^{4}$ Centre for Space Studies of the Biosphere, CESBIO, 18Av. Edouard Belin (2801 BPI) 31401 \\ Toulousecedex9, Toulouse, France. \\ ${ }^{5}$ Litani River Authority, Beirut, Lebanon.
}

\begin{abstract}
Authors' contributions
This work was carried out in collaboration between all authors. Authors TD, IP and RK designed the study, wrote the protocol, managed literature searches and wrote the first draft of the manuscript. Authors ASh, MV, SS, LD and SG performed image processing, climatic modeling, snow simulation and statistical analysis. Author NA managed the analyses of the study. All authors read and approved the final manuscript.

Article Information

DOI: 10.9734/BJAST/2015/13777 Editor(s):

(1) Ahmed Fawzy Yousef, Geology Department, Desert Research Center, Egypt. Reviewers:

(1) Abdel Razik Ahmed Zidan, Irrigation \& Hydraulic Dept., Faculty of Engineering, El Mansoura University, Egypt. (2) Anonymous, Chengdu University of Technology, China. Complete Peer review History: http://www.sciencedomain.org/review-history.php?iid=760\&id=5\&aid=6610
\end{abstract}

Original Research Article
Received $2^{\text {nd }}$ September 2014 Accepted $4^{\text {th }}$ October 2014 Published 23 ${ }^{\text {rd }}$ October 2014

\section{ABSTRACT}

The aim of this paper is to explore the effects and linkages between snow cover areas, distribution, probability and measured water discharge along east Mediterranean coastal watershed using moderate-resolution satellite images (MODIS-Terra). The Nahr Ibrahim River is a typical Lebanese watershed with an area of $326 \mathrm{~km}^{2}$ stretching between the sea and mountainous terrain to the east. 
The largest snow cover often exists in January-February with snow-free conditions between June and November. Image analysis enabled to analyze the temporal variability of the mean and maximum monthly areas of snow cover between 2000 and 2013. Snow cover dynamics were compared with the discharge from main springs (Afqa and Rouaiss) feeding the river and the probability of snow cover was estimated. The mean monthly snow cover, snow melting rates and springs discharge were found to be in direct relationship. In addition, the measured water discharge at the river mouth was found to be higher than the discharge of the two main feeding springs. This indicates a contribution of groundwater to the stream flow, which is again in direct connection with snow melting at the upper bordering slopes and probably from neighboring watersheds. Considering the characteristics of the mountainous rocks (i.e. Sinkholes, fissured and karstified limestone), the pedo-climatic and land cover conditions affect the hydrological regime which is directly responding to the area and temporal distribution of snow cover, which appears after two months from snowing events. This is reflected on water productivity and related disciplines (Agricultural yield, floods). This study highlights the potential of satellite snow detection over the watershed to estimate snow cover duration curve, forecast the stream flow regime and volume for better water management and flood risk preparedness.

Keywords: Snow melt; springs; groundwater; MODIS-Terra; east mediterranean.

\section{INTRODUCTION}

Water shortage in the Middle East-North Africa (MENA) region became a threatening reality with decreased renewable water resources. The available water volume in Lebanon is 500 $\mathrm{m}^{3}$.year ${ }^{-1}$.capita ${ }^{-1}$ compared to international averages of $1700 \mathrm{~m}^{3} /$ year/capita [1]. Following the general trend of unstable precipitation and decline in water quality [2], and despite seasonal water abundance the region is expected to significantly suffer from water scarcity by 2025 . The intergovernmental panel on climate change (IPCC) reports an expected precipitation decrease over the next century by over $20 \%$ for large parts of the MENA region, a likely increase in the frequency and severity of droughts.

The increasing population with expansion of construction areas and rapid urban growth invading river banks and coastal strips has been a principal cause of increased pressure on water resources and land degradation in the Mediterranean countries [3,4]. Therefore, the challenge of water resources management and water allocation under Mediterranean climate during the short periods of water abundance and long episodes of water scarcity will continue to create social and economic challenges, threatening the advance of MENA countries. For this reason, it is important to build national policies, notably in Mediterranean countries relying on satellite derived information on snow cover as major water source, to build national resilience for the efficient use of available water resources during water scarcity periods including flood preparedness and higher water use efficiency. This water policy is apt to ensure the basic needs for sustainable agriculture and other social and industrial needs.

Water budget in Lebanon has been traditionally calculated referring to liquid precipitation measurement from sporadic climatic stations. Thus, the available water resources in Lebanon based on rainfall amount are about $3000 \times 10^{6}$ $\mathrm{m}^{3}$, while the estimated needs exceed $3500 \times 10^{6}$ $\mathrm{m}^{3}$ [5]. However, snow as solid precipitation constitutes the major feeding source of surface and groundwater resources in Lebanon. In high Lebanese mountains it is estimated that 425 $\mathrm{mm} /$ year derived from snow melt are not accounted for [6]. This finding derived from satellite observation and field measurements was confirmed by the review of historical rainfall records of seven climatic stations from North Lebanon with the application of Fisher-Shannon method to analyze the series order and organizational structure showing the rainfall to be less organized and less regular for higher located stations [7]. This problematic picture is complicated by the impact of the complex orography of the country on prevailing rainfall and snow patterns. Winter storms can be followed by sudden increase in temperature enhancing snow melt and surface runoff, flood and soil erosion on the escarpments of the western Lebanese mountains. Groundwater recharge is also highly affected by the geomorphologic features associated with carbonaceous formations which dominate the surface geology of Lebanon, such as developed fracture network (karstification, sinkholes). The stratigraphy of the existing lithology plays a 
significant role in the water flow regime and snow accumulation [8].

Fracturing, faulting and karstic routes as well as acute dips of rock strata seaward serve as hydrological agents transporting groundwater to the sea [9] and complicate the estimation and management of water budget and renewable water resources in the country. Current estimates of water sectorial use indicate that $68 \%$ of available water resources are allocated for agriculture with $46 \%$ reliance on groundwater [10].

Remotely sensed techniques proved to be a valuable tool for monitoring a number of hydrologic processes with a special emphasis on snow cover and surface water flow regime. This is well pronounced in Lebanon, which is known by rugged topographic features and tremendous hydrological aspects. Snowmelt contribution to surface water resources was estimated at $60 \%$ [11]. Snow melt rates are dependent upon different topographic aspects and altitudes; however, it reaches a maximum during MayJune, notably for snowpack located on southfacing slopes. Local observations showed a change in the snowfall pattern and distribution associated with a variable snow area over Lebanon's mountains witnessing accelerated melting rate as a result of increased temperature $[8,12]$.

A recent study based on field observations [13] showed that there is a strong relationship between the snowpack characteristics, such as snow hardness, roughness and density, and their locality. Thus, the snow water equivalent, which mainly depends on the density of the snow, is different with respect to the locality; specifically with the slope, aspect, altitude and also the depth of the snow. Based on these considerations, the objective of this paper is to analyze the spatial and temporal changes in snow area over a typical Lebanese watershed, the Ibrahim River basin, in relation to current and projected snow melting rates, to evaluate the snow cover duration curve (SCDS), snow water equivalent (SWE) and water productivity of two main springs (Afqa and Rouaiss) feeding the $\mathrm{NI}$ River. Monitoring and simulation of space-time variability of the snow cover over the watershed will allow prospecting the probability of snowpack detection and will serve as a decision tool to predict future flow regimes therefore helping assessment of water reserve and water supply as well as flood risk preparedness.

\section{MATERIALS AND METHODS}

Nahr Ibrahim watershed (NIW) is located on the western mountain chain within Jbeil Casa in Lebanon. It covers an area of approximately 326 $\mathrm{km}^{2}$. The watershed is a mountainous area characterized by hills and valleys and falls between $36^{\circ} 2^{\prime} 46^{\prime \prime} \mathrm{E}-34^{\circ} 12^{\prime} 46^{\prime \prime} \mathrm{N}$ and $35^{\circ} 38^{\prime} 35^{\prime \prime} \mathrm{E}$

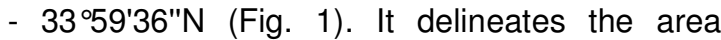
beginning from the mountainous regions at altitude of $2600 \mathrm{~m}$, and its outlet is the downstream of Ibrahim River that joins at the end the sea. The geology of the area is constituted mainly by permeable hard limestone $(\mathrm{C} 4=184$ $\mathrm{Km}^{2} ; \mathrm{J} 6=61 \mathrm{Km}^{2}$ ).

The area comprises agricultural land and residential areas. Drinking water of this region is obtained mainly from Afqa and Roueiss springs both feeding NI. In addition, Household livelihoods are based on agriculture and forest related activities. One river passes through this area: the Ibrahim River having the maximum average discharge among the Lebanese coastal rivers (408 $\times 106 \mathrm{~m}^{3} /$ year). The coastal plain is relatively very narrow and flat ribbon $(<1 \mathrm{~km}$ width) covered by alluvial deposits, which make it suitable for local cultivation activities, urban expansion but it is prone to flood. The slopes extend from the coastal plain upward with a slope gradient of about $20-25 \mathrm{~m} / \mathrm{km}$, and a moderately sharp surface relief.

The catchment is characterized by an obvious biodiversity and classified as an international heritage site [14] where the main sources are the Afqua and Roueiss springs located at an altitude of $1200 \mathrm{~m}$ on Mount Lebanon [15]. These characteristics make the NIW a very important cultural and heritage site representing a diversified landscape type in term of climate condition, geology, morphology, and land use representative of Lebanese environments. But, such an important area suffers from increasing trends of 'land degradation' and is recently witnessing forest fires, soil erosion, flood and increased risks of mass movement and rock falls [16]. Snow cover area data was obtained from the MODIS-Terra snow product MOD10A2 [17] with $500 \mathrm{~m}$ resolution. This product provides the maximum snow cover extent retrieved from MODIS data over a compositing period of 8-day from February 2000 to present. These data were interpolated in case of cloud obstruction following a spatio-temporal method adapted from Parajka and Blöschl [18]. 

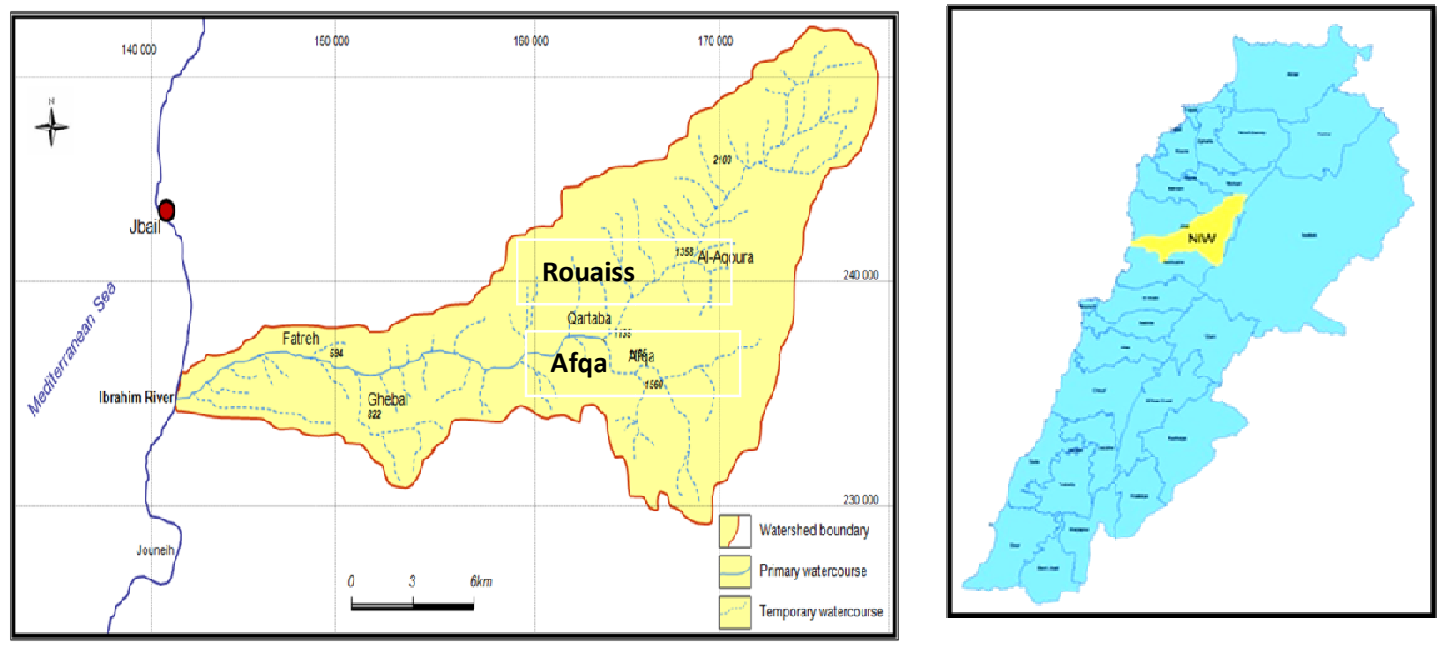

Fig. 1. Location of Nahr Ibrahim watershed in Lebanon

Snow water equivalent observations were carried out on daily basis and aggregated as monthly averages and maximum value. The space-time variability regime of the snow cover using snow cover duration curve (SCDC) was analyzed and the degree day coefficient (DDC) which is very important for the estimation of snow melting rate was considered $8 \mathrm{~mm} /$ day $/{ }^{\circ} \mathrm{C}$ for the region of study [19]. Water balance at the IRW was computed using a new model to simulate the space-time variability of the snow accumulation and melting processes that are recognized as extremely crucial for capturing the hydrological regime of the $\mathrm{NI}$ River and its Karstic springs [20]. Based on these results, a sensitivity analysis was performed considering a DDC of 6 , 8 and $10 \mathrm{~mm} /$ day $/{ }^{\circ} \mathrm{C}$ in relation to expected climate change. For the field calibration indicative selected localities were investigated in details to estimate snow area and snow water equivalent. Daily and monthly discharges from the springs and sea mouth were kindly provided by the Litani Authorities. The Snow Water Equivalent (SWE) was estimated using equation 1.

SWE $=$ Snow extent $\times$ Snow depth $\times$ Snowdensity

\section{RESULTS AND DISCUSSION}

The monthly mean area of snow over NIW between 2000 and 2012 varied between 0.01 $\mathrm{km}^{2}$ and $112.21 \mathrm{~km}^{2}$ with a maximum expansion in February and total absence in summer months (July-September). The mean snow area showed a maximum variability during the snow accumulation months (fall) and snow melting months (spring). The snow cover becomes more stable with lower standard deviation and well established during November-March (Table 1). The average maximum snow area raerched $271.50 \mathrm{~km}^{2}$, which corresponds to $87 \%$ of the watershed area. Average peak values are observed in February and lowest cover in late spring and late summer.

According to recent field measurements, the contribution of snow to river flow is ranging between $30 \%$ and $80 \%$, with an average of about $58 \%$ depending on a miscellany of terrain characteristics [21]. Due to steep slope and narrow cross-sections a high stream flow rate is recorded, which increases water losses from the river into the sea. For this reason, management approaches must focus on water harvesting, such as hill-lakes and dams. The dominant dip direction of rock beds in Ibrahim River basin upper area suggests replenishment of groundwater from the surrounding basins but with similar aquiferous rock formations. The positive water balance, based on gauging station, of the amount of water discharged into the sea compared with the discharge of the two major springs during the 13 years of TerraMODIS observations (2000-2012) apparently support this hypothesis.

A total of $78 \%$ of the NIW constitute hard limestone with significant average infiltration rate varying between $38 \%$ from the volume of liquid rainfall for the Cenomanian (C4) and $40 \%$ for the Jurassic (J6). The estimated infiltration rate drops to $12.5 \%$ for other rock formations present in the watershed [22,23]. Rainfall in the basin varies between $900 \mathrm{~mm}$ on the coastal area and 
Table 1. Dynamics of snow cover in Nahr Ibrahim watershed

\begin{tabular}{llll}
\hline Period & Month & Average mean snow area, $\mathbf{~ k m}^{2}$ & Average maximum snow area, $\mathbf{K m}^{2}$ \\
\hline 1 & $61.24 \pm 26.21$ & $200.19 \pm 28.05$ \\
& 2 & $65.42 \pm 23.60$ & $222.49 \pm 34.47$ \\
$2000-2012$ & 3 & $53.20 \pm 21.04$ & $201.10 \pm 41.53$ \\
& 4 & $12.65 \pm 18.24$ & $75.91 \pm 71.89$ \\
& 5 & $0.46 \pm 1.02$ & $5.04 \pm 7.24$ \\
$6-8$ & 0.00 & 0.00 \\
9 & $0.13 \pm 0.41$ & $3.73 \pm 12.18$ \\
10 & $0.36 \pm 0.39$ & $8.81 \pm 11.24$ \\
11 & $7.57 \pm 9.50$ & $66.98 \pm 67.98$ \\
12 & $36.08 \pm 22.34$ & $180.99 \pm 51.31$ \\
\hline
\end{tabular}

$1700 \mathrm{~mm}$ on mountain peaks. Based on the geomorphology of NIW, from the total amount of water derived from rainfall estimated at $424 \times 10^{6}$ $\mathrm{m}^{3}$ (area $326 \mathrm{Km}^{2} \mathrm{X}$ average rainfall $1300 \mathrm{~mm}$ ) a total of $34.4 \%$ is infiltrated to groundwater and $30.2 \%$ constitutes runoff and the residual $(35.3 \%)$ is lost to evaporation.

However, considering the measured mean annual discharge from Afqa and Rouaiss springs for the same period $\left(128.2\right.$ and $160.3 \times 10^{6} \mathrm{~m}^{3}$ respectively) and estimated runoff $\left(128.0 \times 10^{6}\right.$ $\left.\mathrm{m}^{3}\right)$, the estimated average annual water volume of the IR reaches $416.5 \times 10^{6} . \mathrm{m}^{3}$, which means that against measured mean annual discharge into the sea equivalent to $341.9 \times 10^{6} \cdot \mathrm{m}^{3}$, the annual water abstraction and loss to neighboring watersheds from the $\mathrm{NI}$ is $74.6 \times 10^{6} \cdot \mathrm{m}^{3}$.year ${ }^{-1}$. However, the water discharged by these two springs remains the major source of water in IRW with very high coefficient of determination, notably within the dense cloud shown by the months of low spring discharge, where both rainfall and snowmelt are absent and the river relies mainly on groundwater springs and sporadic rainfall (Fig. 2).

The snow cover fraction of the NIW area derived from MODIS data exceeded $60 \%$ in eleven out of thirteen years of observation (Fig. 3). For other years the snow fraction did not drop below $50 \%$ of the watershed area indicating stable state of average snow cover over high Lebanese peaks potentially ensuring continuous groundwater recharge feeding the very few permanent Lebanese rivers.

The relation between the snow water equivalent (SWE) based on average daily/monthly snow area and the measured flow of the Afqa and
Rouaiss sources is apparently linear (Fig. 4) suggesting the quasi exclusive dependence of spring's water productivity on snow amount and snow melt. However, the SWE based on the maximum daily/monthly snow cover did not show direct correlation with measured flow of both studied springs. This can be probably due to the recurrent storms covering large areas of lower altitudes with shallow snow pack which are often subject to short life cycle and intensive melting promoting surface runoff.

The snow detection probability showed very low recurrence of snow pack at lower locations attributed either to its shallow depth or sudden increase in temperature. Usually such snow at lower altitudes last for several days or less and occur in form of hail. At higher elevations, the snow probability is significantly higher with $40 \%$ of probability to detect snow in these areas (Fig. 5).

However, climatic variability equally affects high altitude as was recorded in December 2010 where MODIS derived data showed a decrease of the area covered by snow in Lebanon from $2400 \mathrm{~km}^{2}$ to $1100 \mathrm{~km}^{2}$ in less than 10 days associated with floods and stressing the high vulnerability of the east Mediterranean peaks to warm winds originated from West Asia and North Africa (Fig. 6). The episode of intensive melting caused by sudden warming was followed by a period of regular snow melting instead of snow accumulation until January 2011 keeping the snow area at the edge of $900 \mathrm{~km}^{2}$. Meanwhile, the average snow area in NIW was reduced from $64.23 \mathrm{~km}^{2}$ to $40.78 \mathrm{~km}^{2}$ in December 2010 and January 2011 respectively. 


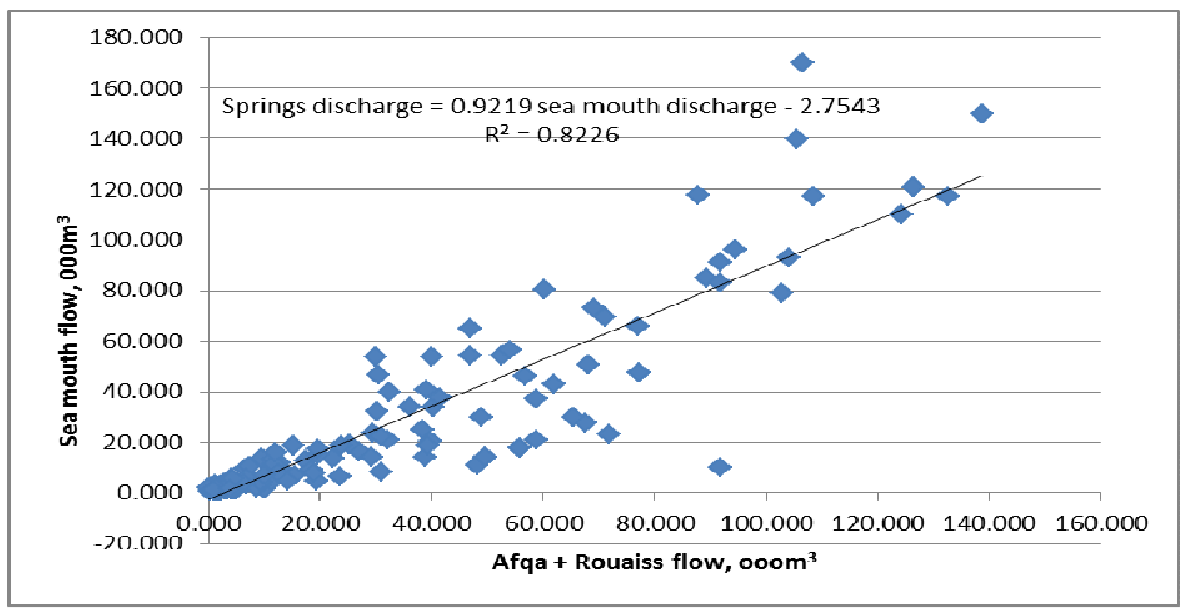

Fig. 2. Long term average contribution of major springs to Ibrahim river discharge

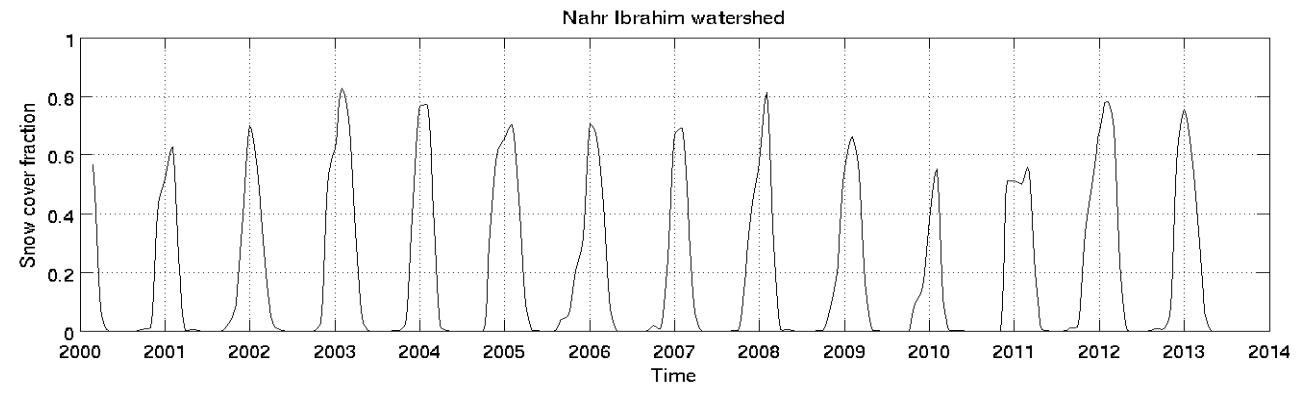

Fig. 3. Temporal state of monthly average snow fraction over the NIW land area

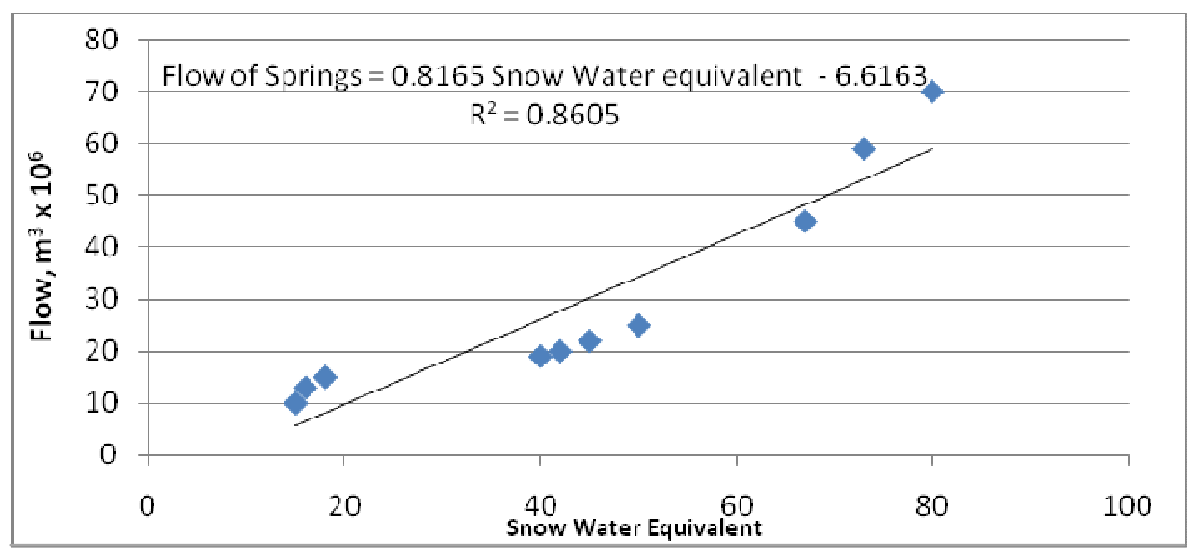

Fig. 4. Snow water equivalent effect on the flow of Afqa and Rouaiss springs feeding NI river

Detecting and monitoring snow cover from satellite images and estimating snow water equivalent can serve as tools to forecast the expected water flow and relate water discharge and water volume with snow melting rate as affected by temperature gradient and fluctuation of positive temperature especially during the snow melting period. Similar hydrological testing uses the flow-duration curves (FDC) to characterize the frequency of discharge values for a river cross section and show the percent of time specified discharges were equaled or exceededd during a given period. 
Based on the long-term flow of a stream, the FDC may be used to predict the distribution of future flows for flood hazard, waterpower, watersupply, and pollution studies. Thanks to the available MODIS-derived daily time series of the snow-covered area for the $\mathrm{NI}$ watershed in the period 2001-2012, it was possible to validate the simulated snow cover. The method used was the sensitivity analysis of the snow cover area to different values of the DDC 4, 6, 8 and 10 $\mathrm{mm} /$ day $/{ }^{\circ} \mathrm{C}$ (Fig. 7) using the snow cover duration curves (SCDC) as indicator of the space-time variability regime of the snow cover to validate the DDC value that provided the best fit to the MODIS snow cover data.

The SCDC plot, although based on the experimental frequency values, has an intrinsic meaning as probability plot of the snow cover area. Therefore, this statistical representation may be used to provide the following elements of information for the $8 \mathrm{~mm} /$ day/C scenario: $30 \%$ (i.e. 3.6 months/year) is the probability that the snow cover is larger than $1 \mathrm{~km}^{2}$; a little less than $20 \%$ (i.e. 2.4 months/year) is the probability of a snow cover larger than $10 \mathrm{~km}^{2}$; a little less than $10 \%$ (i.e. 1.2 months/year) is the probability of a snow cover larger than $100 \mathrm{~km}^{2}$.

The influence of the DDC value over the spacetime variability of the snow cover was also evaluated for DDC values equal to: 4,6 , and 10 $\mathrm{mm} /$ day $/{ }^{\circ} \mathrm{C}$ thus covering a wide spectrum across the $86 \%$ fitting value between simulated and observed snow cover at $8 \mathrm{~mm} /$ day $/{ }^{\circ} \mathrm{C}$ interval. The results of this sensitivity analysis corresponding to optimistic and pessimistic temperature variability scenarios shown in (Fig. 6 $a, b$ and d). Lower DDC values indicate wider snowpack areas compared to those observed by MODIS associated with lower melting rates resulting in larger snow water equivalent and less runoff and evaporation losses and yielding higher water amounts and better recharge conditions. The increase of DDC by $2^{\circ} \mathrm{C}$ resulted in the reduction of snow pack width and probability of snow cover duration resulting in higher evaporation rates and runoff causing flood, soil erosion and deterioration of water quality. Similar results were reported for the area with $\mathrm{T}$ increase resulting in fast reduction of snow width and peak river flow causing flood [24].

Snow cover and snowmelt are responsible for most of the peak discharge values occurring in late winter and spring but other high-flow conditions are found in autumn (e.g. 2006 and 2009) associated to intensive rainfall when the snow cover is not present. The influence of snowmelt on the river discharge is more evident at the monthly scale (Fig. 8) where the higher peaks and the double-peak hydrographs are always driven by the quick snow melting. The contribution of snowmelt to the annual discharge volume is estimated around the $40 \%$ (Fig. 9).

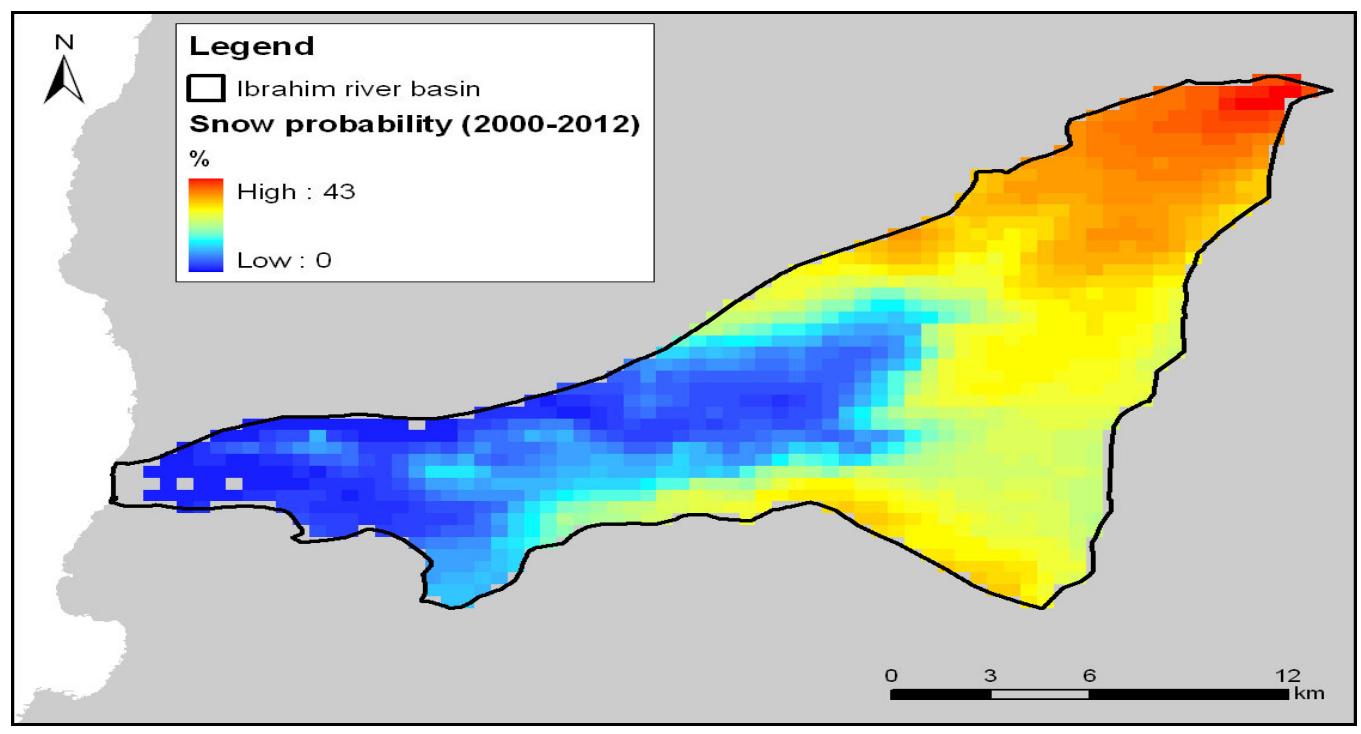

Fig. 5. Snow detection probability (\%) calculated over 2000 - 2012 from MODIS data in the Nahr Ibrahim watershed 


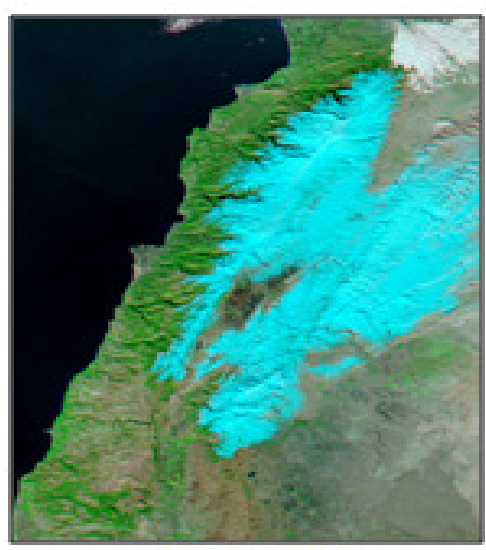

$15 / 12 / 2010$

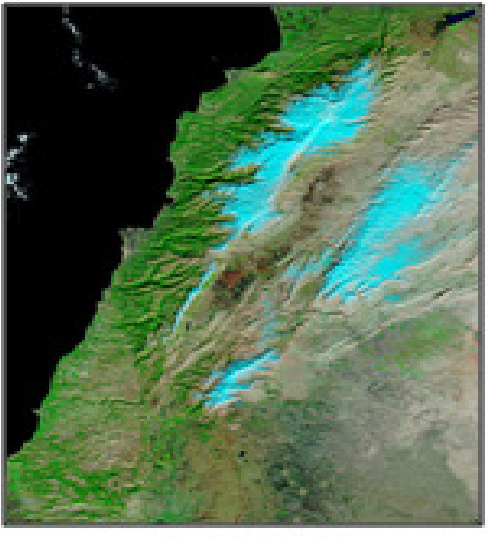

$25 / 12 / 2010$

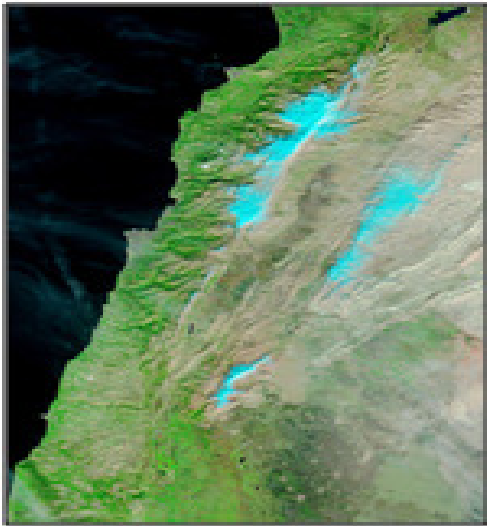

$25 / 1 / 2011$

Fig. 6. Snow area fast reduction caused by sudden increase of temperature over Lebanon (MODIS, bands 7-2-1)
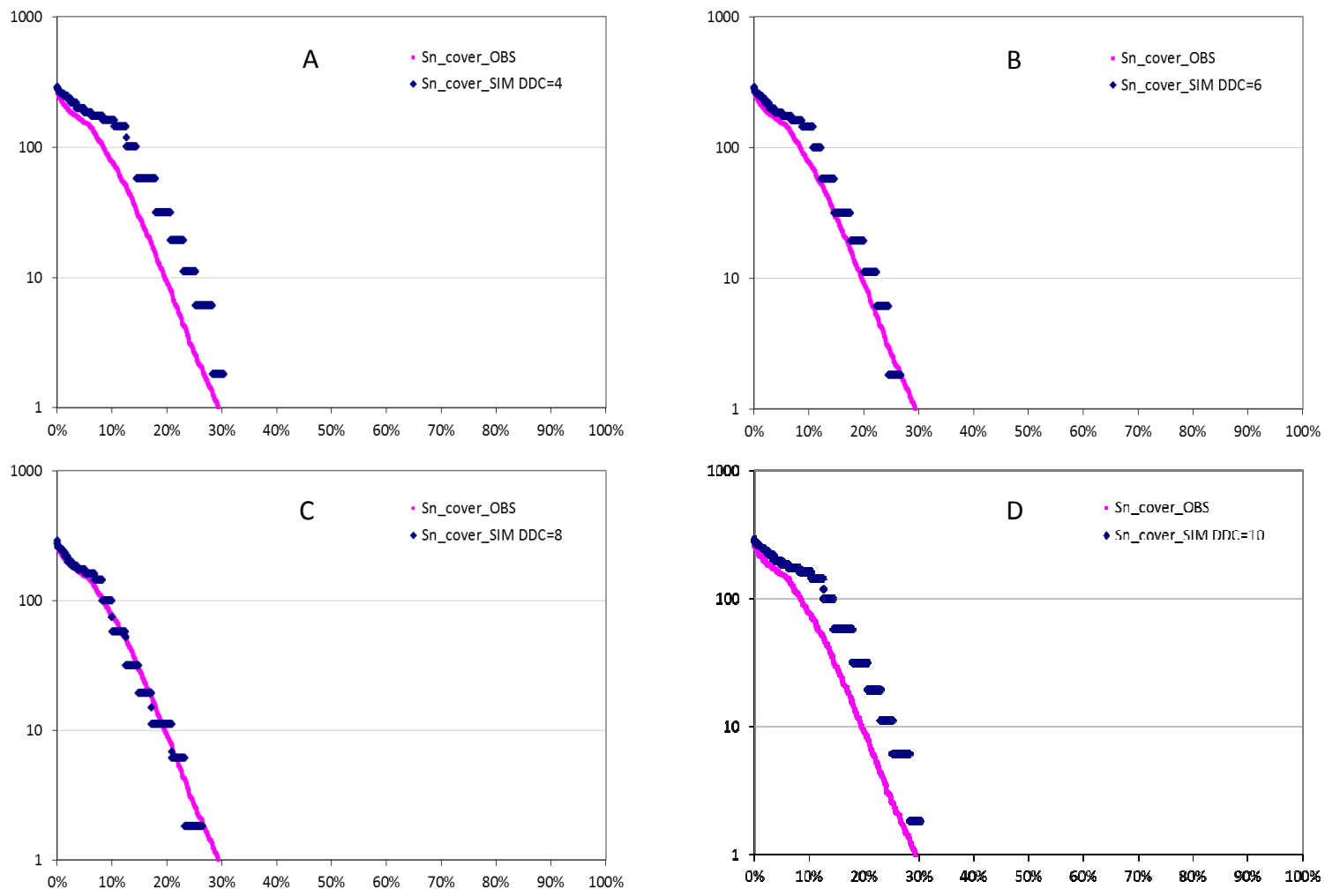

Fig. 7. Simulated (blue dots) and observed (red line) snow cover duration curve based on different degree day coefficient (DDC) of $4,6,8$ and $10 \mathrm{~mm} /$ day $/{ }^{\circ} \mathrm{C}$ 


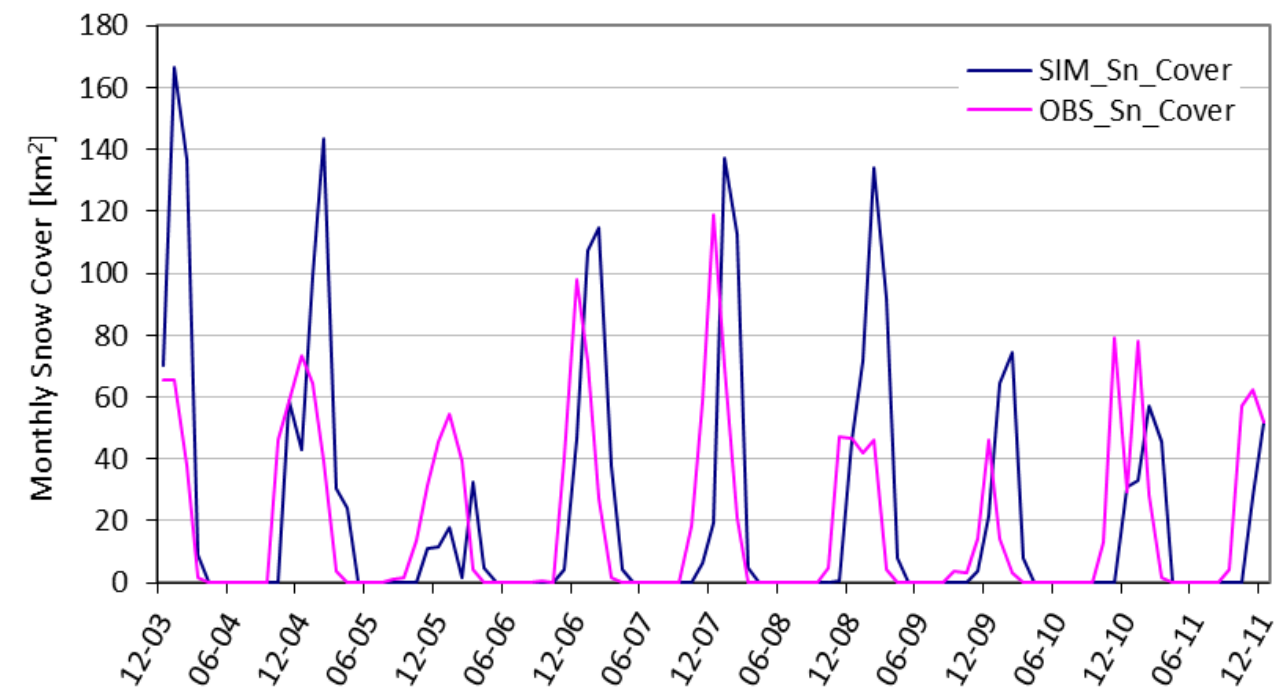

Fig. 8. Simulated and observed dynamics of snow melt and river discharge in NIW

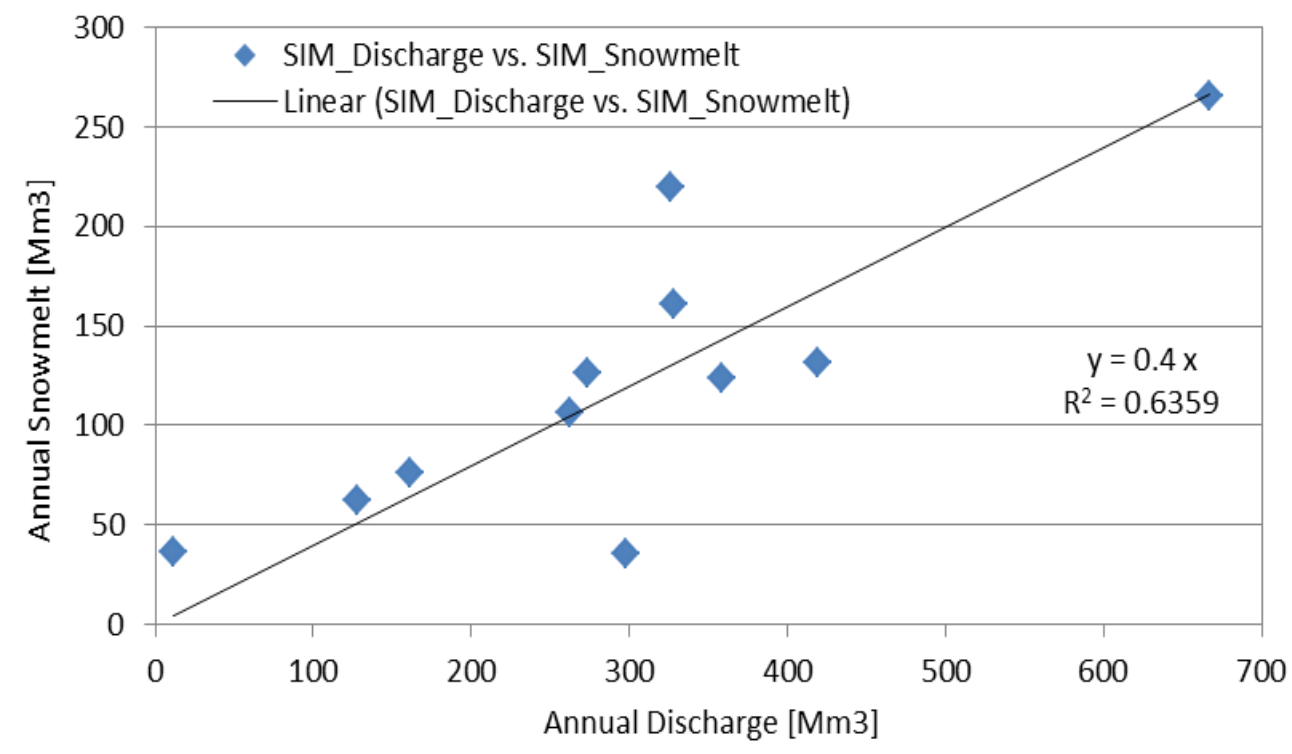

Fig. 9. Effect of annual snowmelt on annual river productivity

\section{CONCLUSION}

Ibrahim River is mainly affected by the main two springs (Afqa and Rouaiss) location, feeding mechanism and productivity providing up to $80 \%$ of river's productivity. Snow cover and high infiltration rate of carbonaceous rocks directly affects the recharge potential and renewability of groundwater and surface water in Ibrahim Watershed. However, the mean daily and monthly values of snow cover observed from remote sensing explained better the relation between snow water equivalent and water discharge from the Afqa and Rouaiss springs compared to the maximum daily and monthly snow area due to different melting rates and abundance of runoff at lower altitudes. The snowmelt volume is consistent with the discharge in terms of timing at the monthly and daily timescales. The simulation showed that snowmelt contributes about $40 \%$ to the annual discharge volume of the studied springs. However, uncertainties remain regarding the reliability of the old national rainfall maps, change 
of rainfall form and intensity with altitudinal gradient and snowpack accumulation pattern according to dominating wind.

\section{ACKNOWLEDGMENTS}

This work was developed within the Cooperative Programme of the Agreement on Scientific Cooperation between The National Research Council of Italy (CNR) and The National Council for Scientific Research of Lebanon (CNRS-L) which funded for the biennial programme 20122013 the research proposal for "Modelling Water Balance Using Remotely Sensed Data: Application to Ibrahim River Basin, Lebanon".

\section{COMPETING INTERESTS}

Authors have declared that no competing interests exist.

\section{REFERENCES}

1. FAO. Irrigation in the Near East Region in Figures. Water Reports.1996;9:135-143.

2. Khawlie M. The coastal system-physical component. Assessment of Lebanon's vulnerability to climate change. Lebanon's National Communication on Climate Change. UNDP/GEF, Beirut; 1999.

3. Eswaran H, Reich P. Impacts of land degradation in the Mediterranean region. Fourth Int. Meet. on Red Med. Soils. Plovdiv, Bulgaria. 1997;11.

4. Darwish T, Faour G, Khawlie M. Assessing soil degradation by landuse-cover change in coastal Lebanon. Lebanese Science Journal. 2004;5:45-59.

5. Saad F. Available Water in Lebanon. Training Course on the use of modern irrigation system. Beirut; 1995.

6. Shaban A, Faour G, Khawlie M, Abdallah C. Remote sensing application to estimate the volume of water in the form of snow on Mount Lebanon. Hydrological Sciences Journal. 2004;49(4):643-653.

7. Lovallo M, Shaban A, DarwichT, Telesca L. Investigating the time dynamics of monthly rainfall time series observed in northern Lebanon by means of the detrended fluctuation analysis and the Fisher-Shannon method. Acta Geophysica; 2013. DOI. 10.2478/s11600-012-0094-9.

8. Shaban A, Darwich $T$. The role of sinkholes in groundwater recharge in mountain crests of Lebanon.
Environmental Hydrology Journal. 2011;19 (9):1-11.

9. Shaban A, Khawlie M, Abdallah C, Faour G. Geologic controls of submarine groundwater discharge: application of remote sensing to north Lebanon. Environmental Geology. 2005;47(4):512522.

10. FAO. Project de Recensement Agricole. Direction des Etudes et de la Coordination du Ministère de l'Agriculture, BeirutLebanon. 1998;59.

11. Abd-El-Al I. Hydrological study on Ibrahim River. UNESCO, Damascus. 1947;2.

12. Shaban A. Indicators and aspects of hydrological drought in Lebanon. Water Resources Management Journal. 2009;23:1875-1891.

13. Shaban A, Darwich T, El Hage M. Studying Snowpack-related Characteristics on Lebanon Mountains. International Journal of Water Sciences. 2013;2:6. DOI: $10.5772 / 57435$.

14. Bou Saab $H$, Nassif $N$, El Samrani $A$, Daoud R, Medawar S. Suivi de la qualité bactériologique des eaux de surface (rivière Nahr Ibrahim, Liban). Revue des Sciences de l'Eau. 2007;20(4):341-352.

15. Korfali S, Davies B. The relationships of metals in river sediments (Nahr-lbrahim, Lebanon) and adjacent flood plain soils. Agricultural Engineering International: The CIGR Journal of Scientific Research and Development Manuscript LW 04010; 2004.

16. Assaker A, Darwish T, Faour G, Noun M. Use of remote sensing and GIS to assess the anthropogenic impact on forest fires in Nahr Ibrahim watershed, Lebanon. Lebanese Science Journal. 2012;13(1):1528.

17. Hall DK, Riggs GA, Salomonson VV, DiGirolamo NE, Bayr KJ. MODIS snowcover products. Remote Sensing of Environment. 2002;83(1-2):181-194.

18. Parajka J, Blöschl G. Spatio-temporal combination of MODIS images-potential for snow cover mapping, Water Resour. Res. 2007;44. W03406, 2008.

19. Hreiche A, Najem W, Bocquillon C. Hydrological impact simulations of climate change on Lebanese coastal rivers/ Simulations des impacts hydrologiques du changement climatique sur les fleuves côtiers Libanais, Hydrological Sciences Journal. 2007;52(6):1119-1133. DOI: 10.1623/hysj.52.6.1119. 
20. Portoghese I, Sagedah S, Vurro M., Darwish T, Shaban A, KhadraR. Modeling Climate Change Impact on the Water Balance of a Coastal Watershed in Lebanon. $\quad 1^{\text {st }}$ CIGR Inter-regional Conference on Land and Water Challenges-Bari (Italy); 2013.

21. Shaban A, Darwich T. Investigating snow characteristics on mountain chains of Lebanon. $1^{\text {st }}$ CIGR Inter-regional Conference on Land and Water Challenges-Bari (Italy); 2013.

22. UNDP. Liban: Study of groundwater. United Nations Programme for Development, N.Y. DP/SF/UN. 1970;44:185.
23. Abbud $M$, Aker $N$. The study of the aquiferous formations of Lebanon through the chemistry of their typical Springs. Leb. Sci. Bull. 1986;2:5-22.

24. Hreiche A, Bocquillon C, Najem W. Parameter estimation of a conceptual rainfall runoff model and application to Mediterranean catchments. In: Complexity and Integrated Resources Management (ed. by C. Pahl-Wostl, S. Schmidt \& T. Jakeman) (iEMSs 2004 Int. Congress). Int. Environmental Modelling and Software Society, Osnabrück, Germany. 2004;11591164.

(0) 2015 Darwish et al.; This is an Open Access article distributed under the terms of the Creative Commons Attribution License (http://creativecommons.org/licenses/by/4.0), which permits unrestricted use, distribution, and reproduction in any medium, provided the original work is properly cited.

Peer-review history:

The peer review history for this paper can be accessed here:

http://www.sciencedomain.org/review-history.php?iid=760\&id=5\&aid=6610 